УAK 339.187: 608.1

M. Abbaszade,

$\mathrm{PhD}$ in Economics, Doctoral candidate,

Institute of Economics of ANAS, c. Baku, Azerbaijan Republic

ORCID ID: 0000-0002-1725-5777

DOI: $10.32702 / 2306-6792.2021 .5-6.82$

\title{
THE MAIN DIRECTIONS OF REGIONAL ECONOMIC DEVELOPMENT IN THE CONDITIONS OF MODERN MARKET ECONOMY
}

\author{
М. Аббасзаде, \\ к. е. н., докторант, Інститут Економіки НАНА, м. Баку, Азербайджан
}

\begin{abstract}
ОСНОВНІ НАПРЯМИ РЕГІОНААЬНОГО ЕКОНОМІЧНОГО РОЗВИТКУ В УМОВАХ СУЧАСНОЇ РИНКОВОЇ ЕКОНОМІКИ
\end{abstract}

The article examines the main directions of regional economic development in the conditions of modern market economy. The experience of developed countries shows that if the state has a socio-economic development policy, the regional development policy is also applied to it. It should be taken into account that economic regions are a territory where different interests and relations are concentrated. In the article shows that the provision of regional socio-economic development is a complex process in relation to different directions of socio-economic development policy. The main reason for this is that the implementation of the regional policy is influenced by a different factors, as well as factors arising from the economic potential of each region. The effectiveness of the country's overall socio-economic development policy depends on the correct implementation of the regional development policy, as well as on the regional territorial structural policy.

Regional policy is especially important for the post-soviet countries. It is impossible to generalize the regions taking into account the differences existing in the natural-geographical, socio-demographic, economic and other spheres of individual economic zones.

The analysis of the article shows that the mentioned discrepancy led to the formation of serious differences in the location of the leading sectors of the national economy in the regions. Statistical analysis shows that different economic regions, industry, agriculture, etc. they differ from each other in the volume of products produced in important areas.

In the article, it was concluded that many problems in the regions do not allow effective use of the existing potential, as well as slow the development of various spheres of the national economy. From this point of view, it is necessary to examine the existing conditions in the regions, many characteristic features and sharp differences in economic development, trends in entrepreneurship development in the regions, ensure balance in economic development, achieve sustainable socio-economic development of the regions.

The article identifies the current problems in the implementation of regional economic development in the conditions of the modern market economy, as well as offers and recommendations for their elimination were are given.

У статті розглядаються основні напрями регіонального економічного розвитку в сучасній ринковій економіці. Аосвід розвинутих країн показує, що подібно до політики соціально-економічного розвитку держави, політика ре- 
гіонального розвитку реалізується адекватно. Таким чином, проблеми, порушені на національному рівні, також порушуються та реалізуються на регіональному рівні. Слід мати на увазі, що економічні регіони - це сфери, де різні інтереси та відносини зосереджені між підприємствами та організаціями, органами державної влади та місцевого самоврядування, а також всередині цих установ. Аналіз статті показує, що забезпечення регіонального соціальноекономічного розвитку є складним процесом стосовно різних сфер політики соціально-економічного розвитку. Основною причиною цього $є$ те, що на реалізацію регіональної політики впливає низка загальнодержавних факторів, а також фактори, що виникають внаслідок економічного потенціалу кожного регіону. Ефективність загальної політики соціально-економічного розвитку країни залежить віА належного зАійснення політики регіонального розвитку, а також регіональної територіальної структурної політики.

Аналіз статті показує, що ця різниця призвела до формування суттєвих відмінностей у розміщенні провідних галузей національної економіки за регіонами. Статистичний аналіз показує, що різні економічні регіони, промисловість, сільське господарство тощо відрізняються за обсягом продукції, виробленої у важливих сферах.

На підставі проведеного в статті досліАження було зроблено висновок, що багато проблем у регіонах не дозволяють ефективно використовувати наявний потенціал, а також уповільнюють розвиток різних галузей національної економіки. 3 цієї точки зору необхідно вивчити існуючі в регіонах ресурси, їх численні характеристики та різкі відмінності в економічному розвитку, тенденції розвитку підприємництва в регіонах, забезпечити рівновагу в економічному розвитку, Аосягти стійкого соціально-економічний розвиток.

У статті визначено існуючі проблеми реалізації регіонального економічного розвитку в сучасній ринковій економіці та висунуто пропозиції та рекомендації щодо їх вирішення.

Keywords: state policy, integration, investment, economic integration, national economy, macroeconomy.

Ключові слова: державна політика, інтеграчіл, інвестичї, економічна інтеграчія, начіональна економіка, макроекономіка.

\section{INTRODUCTION}

It is known that the overall economic progress of the state depends on the level of development of individual regions. In other words, it is impossible to speak of sustainable economic development of any state without the development of individual regions. From this point of view, even in the modern period of rapid development of country, the socio-economic development of the regions has been identified as one of the priorities for the sustainable and dynamic development of the national economy. Therefore, the regional policy determines the main directions of socioeconomic development of individual economic regions, and then the selection of possible measures for the implementation of these directions and the stages and terms of their implementation. Here, at the stage of assessing the real situation, the selection of strategic goals and the identification of deficiencies in infrastructure, organization and resources for the implementation of these goals and their elimination it is important to identify ways to lift it.

Of course, one of the necessary issues for achieving regional development is the more successful implementation of the adopted programs and the development of new programs in this direction. From this point of view, in the 70 s of the last century, the main focus of the country's economy was on the study of theoretical views on regional reproduction and distribution of wealth by regions. At the same time, the issues of maximum efficient use of development potential, efficient involvement of local resources in the economic turnover have not been sufficiently studied in the development of models of sustainable socio-economic development. Last years this is problem remains the subject of discussion.

\section{ANALYSIS OF RECENT PUBLICATIONS ON THIS TOPIC}

Such issues include the effective management of socio-economic potential in the regions, the formation of local and regional markets, as well as their infrastructure, the implementation of appropriate investment policies, the proper use of property of various forms of ownership, ensuring the efficient use of local resources, intensifying efficient use of existing potential, etc. 
In the modern period of accelerated globalization and integration processes, the role of the regional economy in the dynamic socio-economic development of each country and in ensuring economic security has increased.

At the same time, according to many economists, regional science has not been studied enough. For example, V.V.Mishenko always stressed the need for regional economic development in his works [2]. Research shows that issues related to regional economic development were developed by D.V. Kuzmin [1]. He believed that regional science was more comprehensive than the regional economy. At the same time, there is a consensus among these scholars that when studying the methodological aspects of regional science, including economics. It is important to clarify the concept of "region" in the first place. This concept is not clearly defined in the local and foreign scientific literature, and they are interpreted differently depending on the characteristics of the regions.

It is clear from research that the term "region" means a sector of the country, the national economy, which differs in its natural resources and geographical features. These regions are relatively stable in both production, technical and economic relations. Other authors present the region as an administrative unit of the country, for example, a zone, a province, a city. Of course, in both cases, a certain area of the country is considered, which is very important for the proportional development and complementary economic growth of these areas.

Research shows that there have been different approaches to the concepts of economic region, both by local and foreign scholars. Of course, over time, these approaches have changed and developed further.

For example, according to K.N. Abdullayev regional development is main prioritety of each contry. The construction of new factories, roads was considered a major investment in the development of the region. The concept of regional development based on science and innovation [5].

In general, the most commonly used criteria in the formation of the concept of region are geographical aspects, production, urban planning. As can be seen, the region is at the same time an element of the sectoral organization of the national economy, as well as an area of responsibility. It should be considered not only as an element of the settlement system, but also as a social component of society. Because the region is a single system with its own structure, functions, relationships with the environment, history, culture, and living conditions of the population.

Although the main role in the activities of the region is played by the population, labor collectives, effective management of the region.

As a socio-economic system, the region consists of five main subsystems: system-forming base, system service complex, ecology, population and market infrastructure. The main factor that creates the interaction between these subsystems is human activity.

\section{STATEMENT OF THE MAIN MATERIAL}

Based on the above, we can give such a definition to the concept of the region that the region is a territory characterized by the availability of economic, political and administrative structures. There are several methods of defination of regions according to the socio-economic level of development. Due to the variety of features of the social sphere and economic climate, regions can be divided into three groups: developing regions with a high standard of living and production, regions with medium economic potential and regions with a low social economic level.

Balanced and proportionally adapted development of the region's production forces characterizes the regional economy's profitability.

As noted, one of the main conditions of the region is management of administrative territorial division of the country, which is to some extent based on the completeness of the region. Thus, the administrative territorial structures should coordinate all elements of the general economy material production, natural resources, infrastructure potential, labor and etc. While defining the concept of the region, we should not forget the interpretation of the concept of the economic region. Studies show that the economic region an important economic category in the system of social elements. In modern times, the economic region is the main object of regulation and management of the development of the national economy. An economic region is understood to have the same elements and components of public production located and developed in its territory.

As a scientific category, the definition of the concept of economic region, which reflects the general and specific features, can be given as follows: economic region - effective specialization, improvement of the regional ratio of reproduction goods, the element of social production. It is an integrated territorial subsystem that is systematically organized and arises as a result of the process of social division of labor in 
order to increase the efficiency of the national economy. The economic region is characterized not only by the uniformity of development conditions. In general, the economic region can be considered as a system consisting of various subsystems.

Research shows that the creation of an economic region is an objective result of the formation and development of regions as a system of dynamic economic territory. Economic regions is divided into relatively independent systems that differ in their social integrity on the basis of the historically formed general and local conditions of the national economy of the country.

There are several conditions for the formation of an economic region, including historical, socioeconomic and natural conditions [3].

Factors determine the nature of the economic region and stimulate the formation and development of the different regions. In general, the main factors of the formation of the economic region are the factors reflecting the expansion of the natural basis of the economic region. Factors that reflect the governance of society and the economy as a whole. Finally, independent state depends on the level of development of individual regions, the effective use of local potential of the region and etc.

In this sense, regional development is of great socio-economic importance in modern times. Regional economic development reflects the organization and complex development of priority areas, internal problems on a scientific basis.

In general, experience shows that it is impossible to achieve sustainable development of the country without ensuring regional development. Because regional development is one of the important components of the overall socioeconomic development policy of the country.

It has many unique features of regional development policy. One of the main features of this policy is that it is complex reflects the socioeconomic development of the country as a whole at the regional level. In general, the policy of regional development is implemented in the same way as the policy of socio-economic development of the country. In other words, the issues raised at the national level are also challenged and implemented at the regional level. Different interests and relations are concentrated between economic sectors, enterprises and organizations, state and local self-government structures. For this reason, it is more difficult to ensure regional socioeconomic development than other areas of socioeconomic development policy. This is because the implementation of regional development policy is influenced different factors, as well as factors arising from the specific conditions and economic potential of each region. In this regard, the success of the country's overall socio-economic development policy depends on the success of the regional development policy, as well as the success of regional development. much depends on the territorial structural policy. It is clear from the research that the main factors that distinguish economic regions from the economic, geographical and historical point of view are the economic and geographical position, natural conditions and resources [4].

In addition to the above factors that determine the socio-economic development of the regions, the disproportionate distribution of productive forces between the regions, in general, the majority of the population of the region owns land and other real estate. Therefore, they have the necessary capital, as well as conditions for the development of the agricultural sector, including machinery, services, consulting services, infrastructure, processing plants, etc.

Moreover, for to ensure the balanced development of the regions, as mentioned above, the factors that create the differences should be taken into account, and the differences should be eliminated as much as possible [1].

\section{CONCLUSION}

In view of this, it would be expedient to clarify the main goals of regional policy. The goals of regional policy are usually long term. Although the formation of these goals requiring a modern approach to addressing them. In this regard, qualitatively new issues of regional policy are complemented by the following conditions: similarities and differences of management at the central and regional levels; economic authority of the regions. at the same time, as in state policy, the object of regional policy is to protect the territorial integrity of the country; the transition from the administrative management system to the market regulation system, etc [2].

Taking into account the above, as well as the characteristics of globalization and a market economy, we can finally summarize the current strategic goals of regional development as follows: economic reconstruction of old industrial regions and large cities through modernization of infrastructure, improvement of economic situation and conversion of civil lands; developing of living environment in rural areas and formation of an active economic environment, development of local social and industrial infrastructure, 
efficient using of agriculture land areas; stabilization of the socio-economic situation in the regions; identification of potential opportunities of regions and for formation of a favorable investment activity environment to increase economic activity in the regions; continuation of the creation of territorialproduction complexes and production networks in accordance with the development priorities of production, ensuring the efficient use of raw materials, increasing the attractiveness of investment;stimulating the development of export-oriented and import-substituting industries in the regions with favorable conditions; stimulating creation of free economic zones in regions and etc.

\section{$\Lambda$ ітература:}

1. Кузьмин А.В. Национальная конкурентоспособность, глобальная нестабильность и макроэкономическое равновесие. - Москва: Наука, 2015. 222 с.

2. Мищенко В.В. Экономика регионов. Москва: ИК Аналитика, 2012. - 290 с.

3. Ширай В.И. Мировая экономика и международные экономические отношения. Москва: Издательских дом Аашков и К., 2003. $528 \mathrm{c}$.

4. Шакаралиев А.Ш. Экономическая политика государства: торжество устойчивого и стабильного развития. - Баку: Изд. Victory, 2011. - 542 c.

5. Абдуллаев К.Н. The problems state regulation of sustainable regional development "Структурные трансформации национальных экономик в условиях глобализации", Международная научно-практическая конференция, Николаевский национальный университет имени В.А. Сухомлинского. - Николаев: изд. Гельветика, 2014. - С. 224-226.

\section{References:}

1. Kuz'min, D.V. (2015), Nacional'naja konkurentosposobnost', global'naja nestabil'nost' i makrojekonomicheskoe ravnovesie [National competitiveness, global instability and macroeconomic equilibrium], Nauka, Moscow, Russia.

2. Mishhenko, V.V. (2012), Jekonomika regionov [Economy of the regions], IK Analitika, Moscow, Russia.

3. Shiraj, V.I. (2003), Mirovaja jekonomika i mezhdunarodnye jekonomicheskie otnoshenija [World economy and international economic relations], Izdatel'skij dom Dashkov i K., Moscow, Russia.
4. Shakaraliev A.Sh. (2011), Jekonomicheskaja politika gosudarstva: torzhestvo ustojchivogo i stabil'nogo razvitija [Economic policy of the state: the triumph of sustainable and stable development], Izd. Victory, Baku, Azerbaijan.

5. Abdullaev, K.N. (2014), "The problems state regulation of sustainable regional development", Strukturnye transformacii nacional'nyh jekonomik v uslovijah globalizacii. Mezhdunarodnaja nauchno-prakticheskaja konferencija [Structural transformations of national economies in the context of globalization. International Scientific and Practical Conference], Nikolaevskyi Nacional'nyj Universitet imeni V.A. Suhomlinskogo, Nikolaev, Ukraine, pp. 224-226.

Стаття надійшла до редакиії 09.03.2021 p.

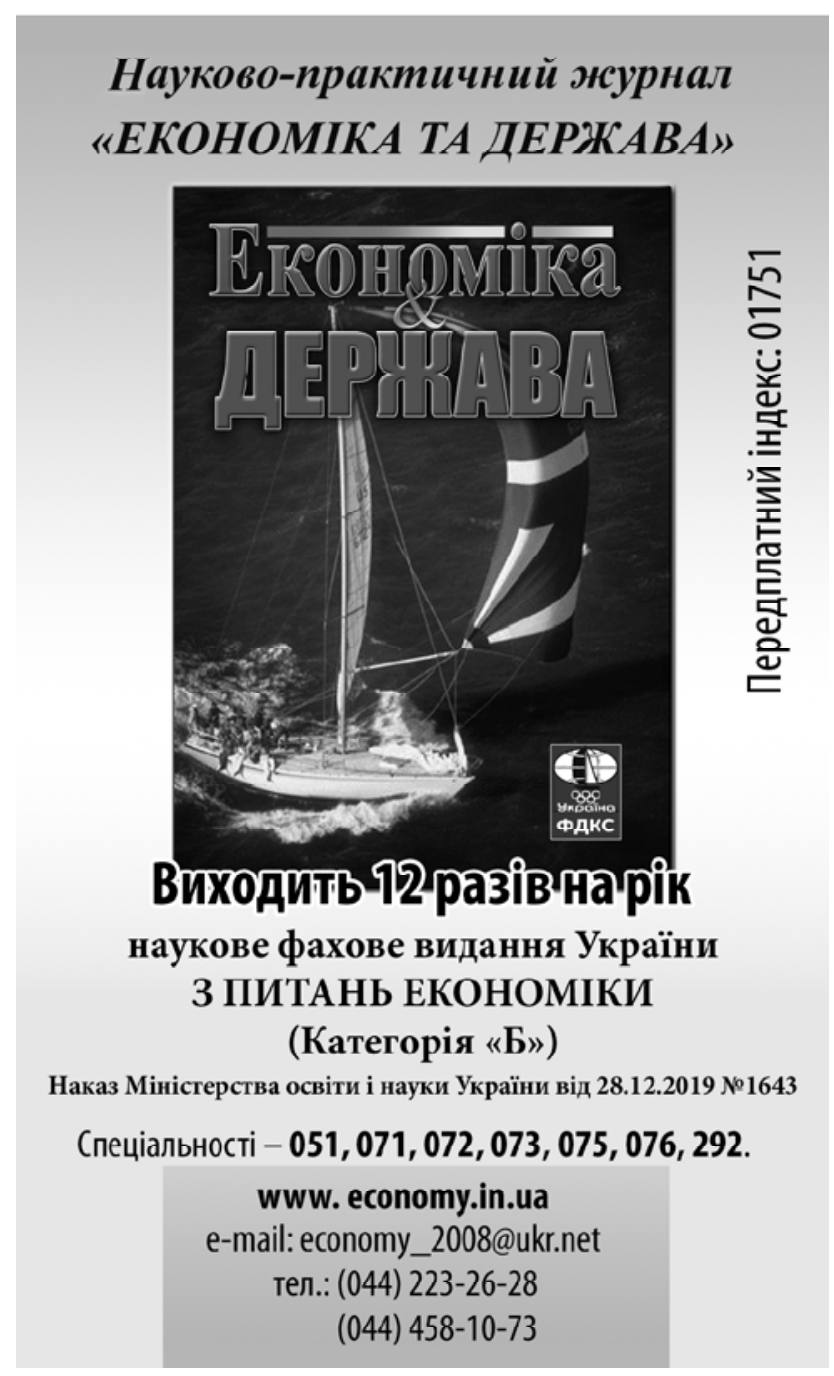

